\title{
Physical variation of non-vegetated marsh edge habitats, and use patterns by nekton in Barataria Bay, Louisiana, USA
}

\author{
Megan K. La Peyre ${ }^{1, *}$, Timothy Birdsong ${ }^{2,3}$ \\ ${ }^{1}$ US Geological Survey, Louisiana Fish and Wildlife Cooperative Research Unit, School of Renewable Natural Resources, \\ Louisiana State University Agricultural Center, Baton Rouge, Louisiana 70803, USA \\ ${ }^{2}$ School of Renewable Natural Resources, Louisiana State University Agricultural Center, Baton Rouge, Louisiana 70803, USA \\ ${ }^{3}$ Present address: Coastal and Inland Fisheries Division, Texas Parks and Wildlife Department, 4200 Smith School Road, \\ Austin, Texas 78744, USA
}

\begin{abstract}
While the ecological importance of vegetated marsh edge habitats for many estuarinedependent nekton is well documented, less is known about nekton use of the non-vegetated, water edge adjacent to marsh habitats and how physical variation of these habitats affects habitat use. The effects of morphological variation of these edge habitats on nekton communities were studied in Barataria Bay, Louisiana, USA. Monthly seining in fall 2003 (September, October, November) and spring 2004 (March, April, May) was conducted at 75 marsh edge study sites $<10 \mathrm{~m}$ from the water-vegetation interface. Morphological variation in edge habitats (i.e. elevation, slope, irregularity) was quantified concurrent with nekton sampling at each sample site. Nekton assemblages were analyzed seasonally as different community assemblages were present in fall and spring, although consistent patterns emerged. Temperature and salinity were the dominant factors influencing nekton assemblages. Edge habitats with shallower slopes and greater marsh inundation supported more organisms and more resident species; in contrast, edges with steeper slopes supported more diverse and species-rich assemblages, possibly providing greater niche availability due to larger water depth gradients and increased edge irregularity, particularly when the adjacent marsh is not flooded. Use of the gently sloped sites by organisms probably reflects increased access to the marsh when flooded, and may provide shallow water refuge for many smaller species. Non-vegetated marsh edge provides valuable habitat for species, and the physical variation that exists within this habitat helps support a high species diversity.
\end{abstract}

KEY WORDS: Non-vegetated marsh edge $\cdot$ Nekton $\cdot$ Nekton community $\cdot$ Louisiana $\cdot$ Edge habitat

Resale or republication not permitted without written consent of the publisher

\section{INTRODUCTION}

Marsh edge environments are a crucial habitat for many estuarine and coastal fisheries. In the northern Gulf of Mexico, the importance of marsh edge habitats in support of estuarine and coastal fisheries production is well documented. It has been estimated that 94 to $98 \%$ of the commercial fisheries catch from the southeastern coastal Atlantic US states and the northern Gulf of Mexico consists of estuarinedependent species (Chambers 1992); commercial yields of these species have been positively correlated with the amount of marsh edge (edge:area ratio) (Turner 1977, Minello \& Rozas 2002). The marsh edge environment (generally defined as $<10 \mathrm{~m}$ from the water- vegetation interface) is often cited as essential fish habitat (EFH) as it serves as a productive nursery area for economically important juvenile finfishes and decapod crustaceans and provides food and refuge for resident and transient predators and their prey (Baltz et al. 1993, Minello 1999, Rozas \& Zimmerman 2000). 
While marsh edge habitats clearly play an important role in the life history of many species, little is known about the significance of marsh edge heterogeneity in structuring nekton communities, or the effects of edge microhabitats on nekton habitat use patterns. Marsh edge habitats are often evaluated in comparison with different habitat types, definable by a single physical habitat characteristic, such as marsh edge versus open water habitats (Rozas \& Zimmerman 2000) or vegetated versus unvegetated environments (Arrivillaga \& Baltz 1999). These single variable definitions of habitat type often fail to incorporate the complexity represented by interacting physical, biological and chemical variables that more probably influence nekton habitat choices throughout different life stages (Minello 1999, Valesini et al. 2004). In many areas, marsh edge habitats exhibit significant heterogeneity in their geomorphology, as well as other enduring environmental characteristics; hence, edge habitats probably represent a wider range of habitat types than is generally acknowledged.

In coastal Louisiana, USA, marsh edge habitats vary structurally from cut-bank erosional edges to gently sloping depositional edges and from relatively straight to more sinuous lengths of shoreline with variation in bank morphology, plant community structure, substrate characteristics, hydrology and landscape position. Differences in emergent or submerged vegetation stem densities may influence habitat availability and the role of the habitat as a predation refuge or a foraging area; a more dense canopy may inhibit the amount of light in the environment and consequently affect the substrate (i.e. detrital material) and the benthic community, while a less dense canopy may fail to provide adequate refuge (Sogard et al. 1987, Heck et al. 2003). Similarly, bank morphology (i.e. slope, irregularity, elevation) may affect exchanges and movement of nutrients, organic material, sediment and organisms to the flooded marsh surface (Rozas \& Reed 1993, Rozas 1995) and influence marsh surface hydroperiod, which directly modifies and determines the physicochemical environment and biota (Patterson \& Mendelssohn 1991).

The present study investigated the physical variation of salt marsh edges in Barataria Bay, Louisiana, and the relationship between edge variables and nekton community characteristics. The objectives of this study are to (1) identify and quantify key variables that describe physical variation in marsh edge habitats, and (2) examine relationships among marsh edge variation, water quality and nekton communities to identify patterns of nekton habitat use. Understanding nekton habitat use patterns and identifying physical indicators of habitat value can help inform the design of marsh protection, restoration and creation projects as well as fisheries management plans.

\section{MATERIALS AND METHODS}

Study location. The study was conducted in Barataria Bay, a 167300 ha estuary located in the deltaic plain of southeastern Louisiana, USA (Fig. 1). Barataria Bay is highly turbid and well mixed, with a mean depth of $1.25 \mathrm{~m}$ and salinity levels that vary between 6 and 22 ppt (Conner \& Day 1987). Tides are diurnal with a range of $0.32 \mathrm{~m}$ and dominated by seasonal winds. Barataria Bay contains numerous small interconnected bays and canals with approximately 145000 ha of saline marsh separated from the northwestern Gulf of Mexico by a chain of barrier islands (Conner \& Day 1987). The bay is bordered to the east by the levees of the current course of the Mississippi River, and to the west by the abandoned Bayou Lafourche distributary, which was closed to riverine input in 1902 (Conner \& Day 1987). The marshes in this area are dominated by

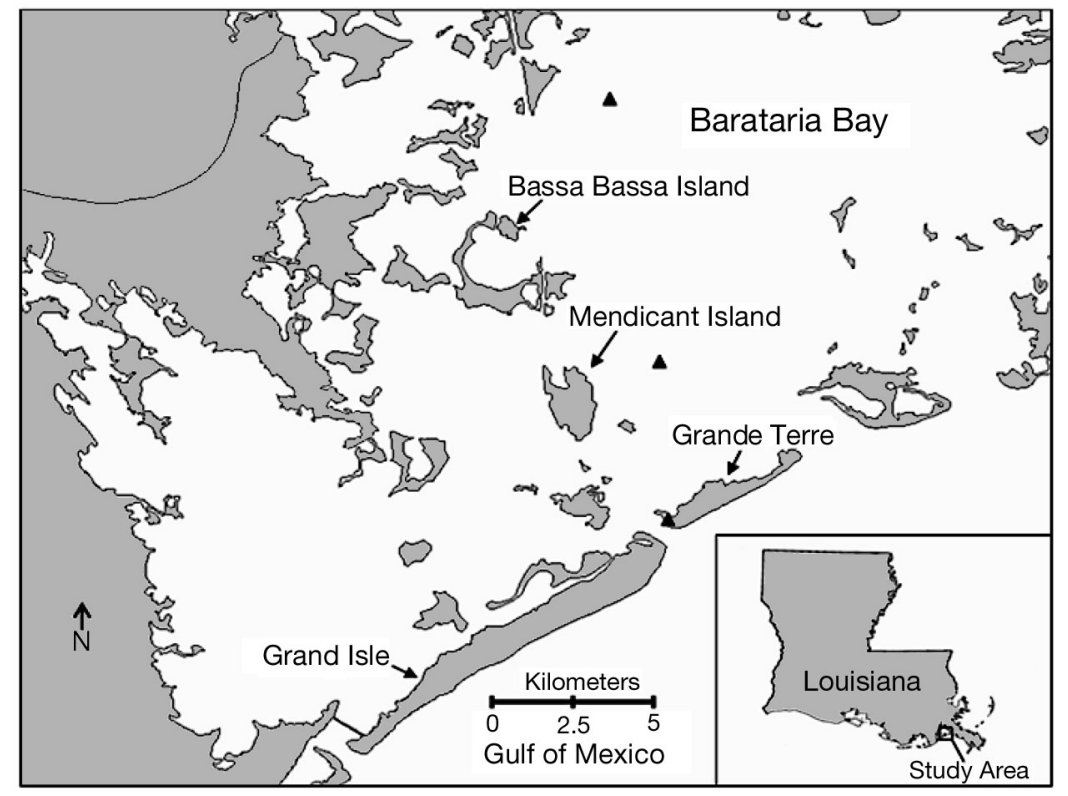

Fig. 1. Study islands (Bassa Bassa, Mendicant, Grande Terre) located in Barataria Bay estuary, Louisiana, USA. Twenty-five sites were sampled on each study island in fall 2003 (September, October, November) and spring 2004 (March, April, May). A: location of US Geological Survey (USGS) meteorological and water quality monitoring stations (from north to south, stations are: USGS 07380251, Barataria Bay north of Grand Isle; USGS 29192908956260, Barataria Bay near Grande Terre Island; USGS 073802515; Barataria Pass east of Grand Isle) 
Spartina alterniflora. Other species present as a very small proportion of the vegetative cover include Juncus roemerianus, Avicennia germinans, Distichlis spicata, Sesuvium postulacastrum and Batis maritima.

Sampling was conducted in the southwestern portion of Barataria Bay at sites selected on Grande Terre, Mendicant and Bassa Bassa islands (Fig. 1). The islands are evenly dispersed along an $11.5 \mathrm{~km}$ transect that extends northwesterly along the Barataria Waterway from Barataria Pass, a major source of saltwater exchange with the Gulf of Mexico located between Grand Isle and Grande Terre Island.

Marsh edge habitats were classified based on visually distinct bank morphology as cut-bank erosional edge (rugged, complex shoreline with exposed plant root systems and a distinct vertical drop between the emergent vegetated marsh edge and the adjacent open-water substrate) or gently sloping edge (smooth, gentle relief and no distinct difference in elevation between the vegetated edge and the open-water substrate). Edges with features in between the 2 types were not selected for the study. In August 2003, each study island was circumnavigated using a surveyor grade Trimble Geo-XT GPS to record marsh edge bank morphology. ESRI ArcGIS 8.1 Geographic Information Systems (GIS) software was then used to map marsh edge morphology on Digital Orthophoto Quarter Quadrangle (DOQQ) images analyzed by the US Geological Survey from color-infrared aerial photographs (1:40 000 scale). Twenty-five $10 \mathrm{~m}$ marsh edge habitats were selected from each island using a stratified random sampling design based on proportional representation of each habitat type. A total of 20 gently sloping habitats (Bassa Bassa, $\mathrm{n}=9$; Mendicant Island, $\mathrm{n}=4$; Grande Terre, $\mathrm{n}=7$ ) and 55 cut-bank habitats (Bassa Bassa, $\mathrm{n}=16$; Mendicant Island, $\mathrm{n}=21$; Grande Terre, $\mathrm{n}=18$ ) were included in the study. In the field, study sites were located with GPS and marked with PVC poles placed $10 \mathrm{~m}$ apart (straight line distance) and flush with the vegetated marsh edge.

Habitat variables. We measured 16 environmental variables during the study. Measures of edge morphology, substrate and vegetation were taken seasonally (December 2003, May 2004) and in triplicate at each site. Measures of edge morphology were selected that potentially affect nekton access onto the marsh surface (i.e. slope, elevation, inundation) or the amount of edge habitat available (i.e. irregularity, bank height). Edge morphology measures included bank height $(\mathrm{cm})$, defined as the height of the vegetated edge above open-water substrate; bank slope $\left(\mathrm{cm} \mathrm{m}^{-1}\right)$, defined as the vertical drop from vegetated edge to substrate at $5 \mathrm{~m}$ horizontal distance from the bank; and shoreline irregularity $(\mathrm{m})$, defined as the length of actual shoreline length per $10 \mathrm{~m}$ straight line length. Measures of vegetation and substrate were selected that might affect nekton assemblages by influencing the area of available refuge (stem density, percent cover, substrate characteristics). Specifically, stem density of marsh edge vegetation (0 to $1 \mathrm{~m}$ on marsh side of marsh-water interface) was measured using $0.10 \mathrm{~m}^{2}$ quadrats and percent cover using $0.25 \mathrm{~m}^{2}$ quadrats. Substrate characteristics were qualitatively assessed by determining the primary and secondary substrate components (i.e. shell, detritus, sand, silt, clay) at 1, 3 and $5 \mathrm{~m}$ from the shoreline.

Meteorological and water quality variables were taken concurrent with nekton sampling at each island. Water quality variables were taken using a YSI Model 556 multiprobe system and included salinity (ppt), temperature $\left({ }^{\circ} \mathrm{C}\right)$ and dissolved oxygen $\left(\mathrm{mg} \mathrm{l}^{-1}\right)$. Meteorological conditions of wind speed $\left(\mathrm{m} \mathrm{s}^{-1}\right)$, wind direction (degrees) and hourly tidal level $(\mathrm{m})$ were downloaded from continuous data recorders adjacent to each site (Fig. 1; www.wlf.louisiana.gov/fishing/ programs/habitat/moreinformation.cfm; recorder numbers 07380251, 291929089562600, 073802515). A relative measure of exposure was developed that incorporated wind speed and wind directional fetch at the time of sampling.

Inundation at each site was measured by subtracting the site elevation $(\mathrm{cm})$ from the tidal level $(\mathrm{cm})$ at the time of sampling. The measure of inundation incorporates several variables that would influence nekton access to the marsh surface including the effects of tides and meteorological forcing. Negative values indicated no direct access, whereas positive values indicated potential nekton access to the marsh surface during sampling.

Nekton sampling. Nekton sampling was conducted monthly in fall 2003 (September, October, November) and spring 2004 (March, April, May) at all study sites during $2 \mathrm{~d}$ sampling periods. A $5 \times 2 \mathrm{~m}$ bag seine composed of $3 \mathrm{~mm}$ square delta mesh was used to sample nekton during the day at each site. The seine was swept parallel along the shoreline between the PVC poles that marked each site for a total distance of $10 \mathrm{~m}$. All nekton was removed from the seine, placed on ice and returned to the laboratory for identification. Nekton was identified to species or lowest taxonomic rank practical, and total length of fishes and shrimp $(\mathrm{cm})$, carapace width of crabs $(\mathrm{cm})$ and wet weights $(\mathrm{g})$ for all 3 groups were recorded. Random subsampling $(\mathrm{n}=30)$ was conducted to obtain length and weight measurements of individuals from abundant species. Total abundance and total biomass of all species were recorded.

Statistical analysis. Multivariate analysis of variance (MANOVA) (SAS Institute 1989) was used to test whether water quality variables (temperature, salinity, 
dissolved oxygen), compared simultaneously, differed among islands and months. ANOVA with StudentNewman-Keuls (SNK) tests were conducted on individual variables following significant MANOVA results $(\mathrm{p}<0.05)$.

To examine the hypothesis that visually distinct cut-bank and sloped sites differ in measurable physical characteristics, MANOVA was used to identify quantitative environmental variables (irregularity, exposure, inundation, slope, stem density, percent cover), compared simultaneously, that differed between these 2 habitat types (cut-bank or sloped). All variables were tested for normality to satisfy the assumptions of the statistical analyses. Subsequent logarithmic $\left(\log _{10}[x+1]\right)$ transformation was necessary only for irregularity, exposure and stem counts. Bank height was not used as it was highly correlated with slope $(\mathrm{p}<$ 0.01 ). Wind speed and direction variables were used to calculate exposure and, thus, were not analyzed separately. ANOVA with SNK tests were conducted on individual variables following significant MANOVA results $(\mathrm{p}<0.05)$.

ANOVA was used to test whether species number, species diversity $\left(H^{\prime}\right)$, catch per unit effort (CPUE), resident fishes (gulf killifish Fundulus grandis, naked goby Gobiosoma bosc, diamond killifish Adinia xenica, bayou killifish Fundulus pulverous, sailfin molly Poecilia latipinna, rainwater killifish Lucania parva, sheepshead minnow Cyprinodon variegatus, darter goby Gobiosoma boleosoma and tidewater silverside Menidia beryllina), and transient fishes (spotted seatrout Cynoscion nebulosus, striped mullet Mugil cephalus, bay anchovy Anchoa mitchilli, silver perch Bairdiella chrysoura, bay whiff Citharichthys spilopterus, lined sole Achirus lineatus, juvenile Atlantic croaker Micropogonias undulatus, blackcheek tonguefish Symphurus plagiusa, red drum Sciaenops ocellatus and juvenile sand trout Cynoscion arenarius) differed among habitat types (cut-bank and sloped), islands or months, by season.

Stepwise multiple regression analysis was used to examine separately associations between quantitative environmental variables and species number, $H^{\prime}$, CPUE, resident finfish, schooling fish and grass shrimp Palaemonetes pugio. Analysis was done separately for fall and spring seasons. Stepwise regression allows for the identification of the most parsimonious model, but also accounts for correlation among variables (Zar 1999). Salinity, temperature, irregularity, slope, inundation, exposure, stem count and percent cover were used as regressors. Only models with an adjusted $\mathrm{R}^{2}>0.1$ are reported.

Fish assemblage data were examined to determine the most appropriate ordination test to use by using the transformation algorithm of detrended correspon- dence analysis (DCA) (Jongman et al. 1995). Canonical correspondence analysis (CCA) was selected and used to relate fish assemblage structure to water quality and physicochemical habitat properties (temperature, salinity, inundation, exposure, slope, irregularity, cover, stem density) (CANOCO; ter Braak \& Smilauer 2002). Total data from fall and spring were analyzed together, followed by seasonal analysis (spring, fall). Rare species ( $<3$ incidences) were excluded from these analyses as they contribute little to the explanative value of the analysis (Gauch 1982). A Monte Carlo test was employed on all canonical axes as a test of significance of the species-environment relationships.

\section{RESULTS}

\section{Environmental variables}

Water temperature ranged between 20 and $28^{\circ} \mathrm{C}$ throughout the 6 mo of sampling, with highest temperatures in May and September and lowest temperatures in November (Table 1). Salinity ranged from 2 to 23 ppt and differed among islands and month. Salinity was greatest at Grande Terre and lowest at Bassa Bassa, with highest salinity at all sites in November and lowest salinity at all sites in May. No differences were recorded in dissolved oxygen among study sites or months and were recorded consistently at $7 \mathrm{mg} \mathrm{l}^{-1}$.

Cut-bank sites were characterized by greater shoreline irregularity, slope, percent cover, stem density, detritus and less inundation than sloped sites (Table 2). Exposure and shell habitat did not differ significantly between cut-bank and sloped sites.

Table 1 . Mean salinity (ppt) and temperature $\left({ }^{\circ} \mathrm{C}\right)$ recorded using a YSI Model 556 multiprobe taken at each study island in September, October and November 2003, and March, April and May 2004. Standard errors are not presented as they were $<0.1$ in all cases. ANOVA found significant differences by island and month for both temperature and salinity. No differences in dissolved oxygen $\left(7.0 \mathrm{mg} \mathrm{l}^{-1}\right)$ were recorded among islands or months during the study

\begin{tabular}{|lcccccc|}
\hline Island & Sep & Oct & Nov & Mar & Apr & May \\
\hline Temperature ${ }^{\circ} \mathbf{C}$ ) & & & & & & \\
Grande Terre & 28 & 23 & 22 & 22 & 23 & 28 \\
Mendicant Island & 28 & 22 & 22 & 22 & 23 & 28 \\
Bassa Bassa & 28 & 23 & 20 & 22 & 23 & 28 \\
Salinity (ppt) & & & & & & \\
Grande Terre & 20 & 21 & 23 & 21 & 22 & 13 \\
Mendicant Island & 20 & 18 & 22 & 20 & 22 & 12 \\
Bassa Bassa & 18 & 18 & 20 & 14 & 16 & 2 \\
\hline
\end{tabular}


Table 2. Results of 1-factor ANOVA testing for significant differences in physical environmental variables by edge type (cut-bank versus slope). SNK was used post-ANOVA following detection of significant results; mean values (SE) are presented for each edge type. ${ }^{*} \mathrm{p}<0.05$

\begin{tabular}{|lcc|}
\hline Variable & Cut-bank & Slope \\
\hline Irregularity $(\mathrm{m})^{*}$ & $13.5(0.1)$ & $10.2(0.2)$ \\
${\text { Inundation }(\mathrm{cm})^{*}}_{\text {Slope }\left(\mathrm{cm} \mathrm{m}^{-1}\right)^{*}}$ & $-2.3(0.8)$ & $23.7(1.7)$ \\
Detritus $^{*}$ & $11.8(0.2)$ & $6.4(0.3)$ \\
Stem density (no. stems m$\left.^{-2}\right)^{*}$ & $0.7(0)$ & $0.6(0)$ \\
Percent cover $(\%)$ & $80.9(1.6)$ & $23.3(2.2)$ \\
& & $52.8(0)$ \\
\hline
\end{tabular}

\section{Nekton assemblages}

A total of 67873 individuals from 56 species and 32 families were collected in 220 seine hauls conducted over the course of fall sampling; 5 sites were not sampled due to storms and boat problems. Grass shrimp Palaemonetetes pugio, penaeid shrimp Penaeus spp., tidewater silverside Menidia beryllina, and bay anchovy Anchoa mitchilli comprised over 96\% of the total catch and occurred in the majority of samples. Gulf killifish Fundulus grandis, naked goby Gobiosoma bosc, gulf menhaden Brevoortia patronus, juvenile red drum Sciaenops ocellatus, blue crab Callinectes sapidus, silver perch Bairdiella chrysoura and juvenile spotted trout Cynoscion nebulosus were also present in the majority of samples (Table 3).

In spring 2004, a total of 31550 individuals from 31 species and 19 families were collected in 217 seine hauls from the same 75 stationary study sites used for the fall samples. Eight of the original sites were no longer available for sampling due to extensive infilling from sedimentation at these sites. The catch consisted of the same numerically dominant species collected in fall 2003 with the addition of high abundances of juvenile striped mullet Mugil cephalus, juvenile spot Leiostomus xanthurus, juvenile sand trout Cynoscion arenarius, juvenile Atlantic croaker Micropogonias undulatus and juvenile silver perch Bairdiella chrysoura (Table 3).

CCA of the total data set (fall and spring) indicated a strong relationship between fish assemblage structure and environmental variables ( $p<0.01$; Table 4 ). The first axis accounted for $53.6 \%$ of the variance and was strongly correlated with fall and spring (0.81) seasons with similar distinctions of dominant species as noted previously; in fall, Callinectes sapidus (CS), Brevoortia patronus (BP), Fundulus grandis (FG) and Gobiosoma bosc (GB) were present, along with some of the species unique to the fall col- lection, including Selene vomer (SV), Eucinostomus melanopterus (EM) and Eucinostomus argenteus (EA). In contrast, Mugil cephalus (MC), Micropogonias undulatus (MU) and Leiostomus xanthurus (LX) were associated with the spring season. The second axis accounted for $30.6 \%$ of the variance and was correlated with temperature $(-0.66)$ and inundation (-0.40). Bairdiella chrysoura (BC), Sphoeroides parvus (SR) and Conodon nobilis (CN) were several species associated strongly with the second axis. Due to the distinct seasonal assemblages, further analyses were conducted by season and are discussed in the following sections.

\section{Effects of environmental variables on nekton diversity and abundance}

Fall

Species number varied significantly among islands, with significantly higher numbers at the lowest salinity site, Bassa Bassa, than at Grande Terre or Mendicant islands (Table 5). Both species number and diversity differed significantly by month, with higher numbers and diversity in September compared with October and November. Both species number and diversity had a trend of higher number and diversity at cut-bank compared with sloped sites, although they were not significant (Table 5). The CPUE was significantly related to type, island and month, with CPUE greatest at sloped sites, at Grande Terre compared with Mendicant and Bassa Bassa, and highest in October and September compared with November. Because over $68 \%$ of the catch consisted of Palaemonetes pugio individuals, they were removed from the data set for CPUE and analyzed separately. P. pugio numbers were found to vary significantly by type, island and month, with highest catch numbers on sloped versus cut-bank edges, at Bassa Bassa Island and in November. Resident fish were more abundant at Grande Terre Island and in October compared with other islands and months. Transient fish did not differ in abundance between edge types, but were more abundant in September.

Multiple regression using water quality and physical habitat variables indicated that species number was positively related to temperature and inundation (Table 6). Diversity was positively related to temperature and slope and negatively related to salinity, while Palaemonetes pugio numbers were negatively related to temperature and slope. Resident fish were negatively related to temperature, slope, stem density and irregularity and positively related to the percent cover of vegetation. 
Table 3. Total catch and mean catch per unit effort (SE) by species with catch greater than 3 individuals for fall 2003 and spring 2004 at cut-bank and gently sloping marsh edge habitats

\begin{tabular}{|c|c|c|c|c|c|c|c|c|c|c|}
\hline \multirow[t]{3}{*}{ Species } & \multirow[t]{3}{*}{ Code } & \multicolumn{4}{|c|}{ Fall 2003} & \multicolumn{4}{|c|}{ Spring 2004} & \multirow{3}{*}{$\begin{array}{c}\text { Total } \\
\mathrm{N}\end{array}$} \\
\hline & & \multicolumn{2}{|c|}{ Cut-bank } & \multicolumn{2}{|c|}{ Gently sloping } & \multicolumn{2}{|c|}{ Cut-bank } & \multicolumn{2}{|c|}{ Gently sloping } & \\
\hline & & $\mathrm{N}$ & Mean (SE) & $\mathrm{N}$ & Mean (SE) & $\mathrm{N}$ & Mean (SE) & $\mathrm{N}$ & Mean (SE) & \\
\hline Palaemonetes pugio & $\mathrm{PP}$ & 19401 & $121.3(28.9)$ & 27058 & $453.3(140.2)$ & 6913 & $44.3(7.8)$ & 3139 & $59.7(16.8)$ & 56711 \\
\hline Menidia beryllina & MB & 6027 & $37.7(7.5)$ & 1696 & $31.4(8.1)$ & 11684 & $71.4(17.7)$ & 2892 & $54.8(18.2)$ & 22299 \\
\hline Anchoa mitchilli & $\mathrm{AM}$ & 5383 & $33.6(9.2)$ & 1177 & $21.8(9.2)$ & 1598 & $9.8(1.5)$ & 164 & $3.2(1.6)$ & 8322 \\
\hline Penaeus spp. & PS & 3103 & $19.4(3.4)$ & 1608 & $29.3(8.2)$ & 1133 & $7.3(1.4)$ & 310 & $5.8(1.4)$ & 6154 \\
\hline Mugil cephalus & $\mathrm{MC}$ & 3 & $0(0)$ & 1 & $0(0)$ & 1357 & $8.4(2.2)$ & 730 & $14.0(6.1)$ & 2091 \\
\hline Leiostomus xanthurus & LX & 3 & $0(0)$ & 0 & & 563 & $3.3(1.2)$ & 41 & $1.2(0.5)$ & 607 \\
\hline Callinectes sapidus & CS & 377 & $2.4(0.4)$ & 139 & $2.6(0.7)$ & 88 & $0.6(0.2)$ & 8 & $0.3(0.2)$ & 602 \\
\hline Sciaenops ocellatus & SO & 468 & $2.9(1.0)$ & 61 & $0.7(0.3)$ & 5 & $0(0)$ & 12 & $0.2(0.1)$ & 546 \\
\hline Bairdiella chrysoura & $\mathrm{BC}$ & 185 & $1.2(0.3)$ & 88 & $1.6(0.7)$ & 215 & $0.4(0.1)$ & 41 & $0.7(0.4)$ & 529 \\
\hline Brevoortia patronus & $\mathrm{BP}$ & 96 & $0.6(0.2)$ & 9 & $0.2(0.1)$ & 332 & $2.0(0.7)$ & 9 & $0.1(0.1)$ & 445 \\
\hline Cynoscion arenarius & $\mathrm{CA}$ & 51 & $0.3(0.2)$ & 9 & $0.2(0.1)$ & 332 & $0.4(1.1)$ & 9 & $0.2(0.1)$ & 401 \\
\hline Fundulus grandis & $\mathrm{FG}$ & 158 & $1.0(0.3)$ & 89 & $1.6(0.5)$ & 1 & $0(0)$ & 0 & & 248 \\
\hline Cynoscion nebulosus & $\mathrm{CY}$ & 119 & $0.7(0.2)$ & 46 & $0.9(2.2)$ & 11 & $0.5(0.1)$ & 2 & $0(0)$ & 178 \\
\hline Micropogonias undulatus & MU & 3 & $0(0)$ & 0 & & 85 & $0.6(0.1)$ & 30 & $0.5(0.3)$ & 118 \\
\hline Gobiosoma bosc & GB & 45 & $0.3(0.2)$ & 69 & $1.3(0.5)$ & 2 & $0(0)$ & 1 & $0(0)$ & 117 \\
\hline Stongylura marina & SM & 6 & $0(0)$ & 3 & $0.1(0)$ & 35 & $0.2(0.1)$ & 12 & $0.2(0.1)$ & 56 \\
\hline Syngnathus louisianae & SL & 23 & $0.1(0)$ & 14 & $0.3(0.1)$ & 3 & $0(0.2)$ & 5 & $0.1(0.1)$ & 45 \\
\hline Symphurus plagiusa & $\mathrm{SP}$ & 18 & $0.1(0)$ & 10 & $0.2(0.1)$ & 6 & $0(0)$ & 0 & & 34 \\
\hline Caranx hippos & $\mathrm{CH}$ & 33 & $0.2(0.2)$ & 0 & & 1 & $0(0)$ & 0 & & 33 \\
\hline Eicropogonias argenteus & EA & 20 & $0.1(0.1)$ & 11 & $0.2(0.1)$ & 0 & & 0 & & 31 \\
\hline Lagodon rhomboids & LR & 12 & $0.1(0)$ & 4 & $0.1(0)$ & 13 & $0.1(0)$ & 2 & $0(0)$ & 31 \\
\hline Oligoplites saurus & OS & 22 & $0.1(0)$ & 8 & $0.1(0.1)$ & 0 & & 0 & & 30 \\
\hline Eucinostomus melanopterus & EM & 24 & $0.2(0.1)$ & 0 & & 0 & & 0 & & 24 \\
\hline Poecilia latipinna & PL & 21 & $0.1(0.1)$ & 1 & $0(0)$ & 0 & & 0 & & 22 \\
\hline Harengula jaguana & $\mathrm{HJ}$ & 22 & $0.1(0.1)$ & 0 & & 0 & & 0 & & 22 \\
\hline Syngnathus scovelli & SS & 5 & $0(0)$ & 1 & $0(0)$ & 7 & $0(0)$ & 7 & $0.1(0.1)$ & 20 \\
\hline Gobionellus boleosoma & GO & 13 & $0.1(0)$ & 3 & $0.1(0)$ & 2 & $0(0)$ & 1 & $0(0)$ & 19 \\
\hline Citharichthys spilopterus & $\mathrm{CP}$ & 1 & $0(0)$ & 3 & $0.1(0) 1$ & 2 & $0(0)$ & 12 & $0.2(0.2)$ & 18 \\
\hline Microgobius gulosus & MG & 10 & $0.1(0)$ & 4 & $0(0)$ & 2 & $0(0)$ & 1 & $0(0)$ & 17 \\
\hline Fundulus similis & FS & 6 & $0(0)$ & 6 & $0.1(0.1)$ & 4 & $0(0)$ & 0 & & 16 \\
\hline Pogonias cromis & $\mathrm{PC}$ & 6 & $0(0)$ & 1 & $0(0)$ & 7 & $0(0)$ & 0 & & 14 \\
\hline Chaetodipterus faber & FB & 11 & $0.1(0)$ & 0 & & 0 & & 0 & & 11 \\
\hline Adinia xenica & AX & 1 & $0(0)$ & 9 & $0(0)$ & 0 & & 0 & & 10 \\
\hline Sardinella aurita & SA & 8 & $0(0)$ & 0 & & 0 & & 0 & & 8 \\
\hline Achirus lineatus & $\mathrm{AL}$ & 0 & & 6 & $0.1(0.1)$ & 0 & & 0 & & 6 \\
\hline Arius felis & $\mathrm{AF}$ & 6 & $0(0)$ & 0 & & 0 & & 0 & & 6 \\
\hline Sphoeroides parvus & SR & 1 & $0(0)$ & 0 & & 5 & $0(0)$ & 0 & & 6 \\
\hline Dasyatis sabina & $\mathrm{DS}$ & 6 & $0(0)$ & 0 & & 0 & & 0 & & 6 \\
\hline Cyprinodon variegatus & $\mathrm{CV}$ & 2 & $0(0.1)$ & 2 & $0(0)$ & 0 & & 0 & & 4 \\
\hline Selene vomer & SV & 4 & $0(0)$ & 0 & & 0 & & 0 & & 4 \\
\hline
\end{tabular}

Table 4. Canonical correspondence analysis results of fish assemblage structure and environmental variables for the total data set. Presented are eigenvalues and cumulative percentage variance of species-environment relationships. Species with fewer than 3 individual observations were excluded from analysis

\begin{tabular}{|lcc|}
\hline Axis & Eigenvalue & Cumulative \% variance \\
\hline 1 & 0.350 & 53.6 \\
2 & 0.200 & 84.2 \\
3 & 0.043 & 90.7 \\
4 & 0.027 & 94.9 \\
\hline
\end{tabular}

\section{Spring}

Species number varied significantly among islands and months with significantly higher numbers at Grande Terre, and in May, the warmest month (Table 5). Diversity differed significantly by month with highest diversity in May. The CPUE varied significantly by island and month with highest CPUE at Grande Terre and in May. While catch consisted of $46 \%$ Palaemonetes pugio, the model results were the same for CPUE with and without $P$. pugio in the model. For consistency with fall results, we report CPUE without $P$. pugio included. $P$. pugio alone varied signifi- 


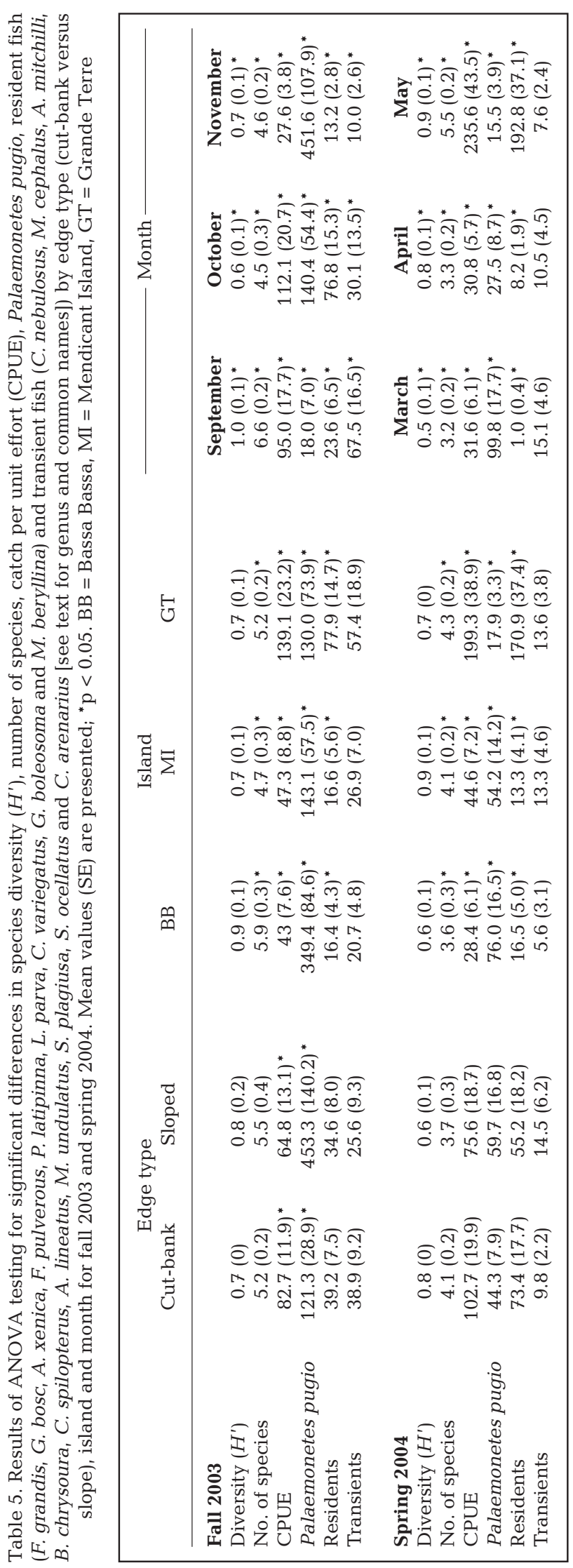

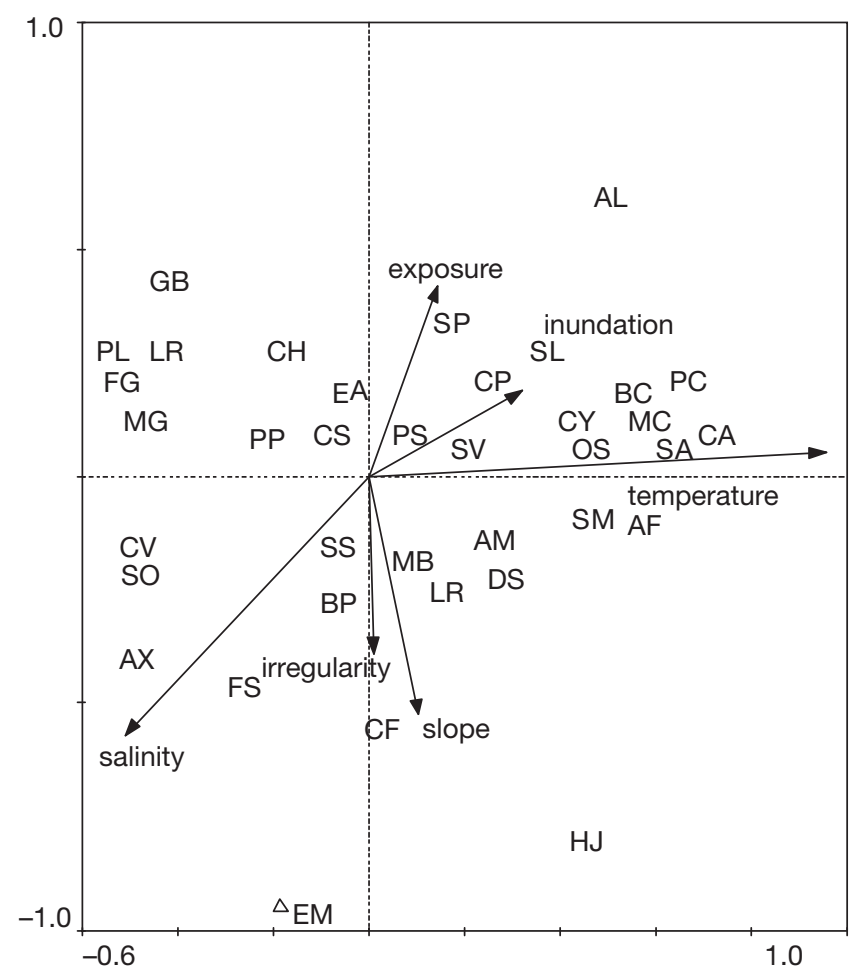

Fig. 2. Association of nekton species and physicochemical characteristics of sampling sites from a canonical correspondence analysis of nekton abundance from fall 2003 sampling of Barataria Bay. Species codes are listed in Table 3

cantly by island and month, with highest catches at Bassa Bassa and in March, unlike results for CPUE. Resident fish were more abundant at Grande Terre and in May compared with other months and islands and did not vary by edge type.

Multiple regression using water quality and physical habitat variables indicated that species number and diversity were both positively related to temperature and slope (Table 6). Without Palaemonetes pugio included CPUE was positively related to temperature, salinity and slope, while $P$. pugio was found to be negatively related to temperature and salinity. Schooling fish were positively related to temperature and salinity.

\section{Effects of environmental variables on nekton assemblages}

Fall

The CCA indicates a strong relationship between fish assemblage structure and environmental variables ( $p>0.01$; Fig. 2). The first axis, which accounted for 
Table 6. Significant results $(\mathrm{p}<0.05)$ of multiple regression analysis showing relationships between environmental variables and diversity $\left(H^{\prime}\right)$, number of species, CPUE, resident fishes (F. grandis, G. bosc, A. xenica, F. pulverous, P. latipinna, L. parva, C. variegatus, G. boleosoma and M. beryllina), transient fishes (C. nebulosus, M. cephalus, A. mitchilli, B. chrysoura, C. spilopterus, A. lineatus, M. undulatus, S. plagiusa, S. ocellatus and C. arenarius) and Palaemonetes pugio. Values indicate the partial $\mathrm{r}^{2}$ for significant variables $(\mathrm{p}<0.15) ;-$ : negative relationships. $\mathrm{F}=$ fall 2003; $\mathrm{S}=$ spring 2004

\begin{tabular}{|c|c|c|c|c|c|c|c|c|c|c|c|c|}
\hline \multirow[t]{2}{*}{ Variable } & \multicolumn{2}{|c|}{$H^{\prime}$} & \multicolumn{2}{|c|}{ No. of species } & \multicolumn{2}{|c|}{ CPUE } & \multicolumn{2}{|c|}{ Resident } & \multicolumn{2}{|c|}{ Transient } & \multicolumn{2}{|c|}{ P. pugio } \\
\hline & $\mathrm{F}$ & $\mathrm{S}$ & F & $\mathrm{S}$ & $\mathrm{F}$ & $\mathrm{S}$ & $\mathrm{F}$ & $\mathrm{S}$ & $\mathrm{F}$ & $\mathrm{S}$ & $\mathrm{F}^{1}$ & $\mathrm{~S}$ \\
\hline Temperature $\left({ }^{\circ} \mathrm{C}\right)$ & 0.22 & 0.07 & 0.18 & 0.26 & $0.04(-)$ & 0.08 & $0.06(-)$ & & & & $0.07(-)$ & $0.07(-)$ \\
\hline Salinity (ppt) & $0.01(-)$ & & & & 0.01 & 0.01 & & & & & & $0.07(-)$ \\
\hline Irregularity (m) & & & & & & & $0.01(-)$ & & & & & \\
\hline Slope $\left(\mathrm{cm} \mathrm{m}^{-1}\right)$ & 0.03 & 0.05 & & 0.02 & $0.03(-)$ & & $0.03(-)$ & & 0.02 & & $0.04(-)$ & \\
\hline Inundation & & & 0.01 & & 0.01 & & & & 0.01 & & & \\
\hline Stem & & & & & & & $0.01(-)$ & & 0.02 & & & \\
\hline Cover & & & & & & & 0.02 & & & & & \\
\hline $\mathrm{R}^{2}$ adjusted & 0.26 & 0.12 & 0.19 & 0.28 & 0.09 & 0.09 & 0.15 & - & 0.06 & - & 0.10 & 0.14 \\
\hline
\end{tabular}

$59.3 \%$ of the variance, was best defined by temperature $(0.80)$ and salinity $(-0.43)$. This first axis represents site and month differences that separated species found in the warmer month (September) from the cooler months (October, November) and at low salinity sites versus those found at higher salinity sites. Species such as Adinia xenica (AX), Sciaenops ocellatus (SO) and Fundulus similis (FS) were more abundant at sites with greater salinity, while species such as Cynoscion arenarius (CA) were more abundant at higher temperatures. The second axis, which accounted for $16.8 \%$ of the variance, was best defined by slope $(-0.27)$. Species such as Chaetodipterus faber (CF), Eucinostomus melanopterus (EM) and Harengula jaguana (HJ) were associated with steeper slopes.

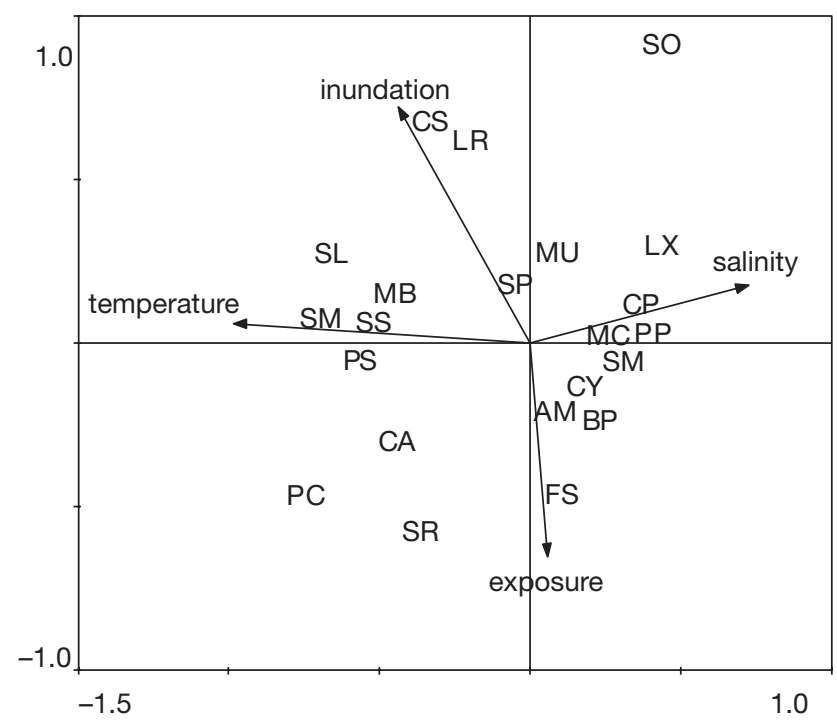

Fig. 3. Association of nekton species and physicochemical characteristics of sampling sites from a canonical correspondence analysis of nekton abundance from spring 2004 sampling of Barataria Bay. Species codes are listed in Table 3
Spring

The CCA indicates a strong relationship between fish assemblage structure and environmental variables $(\mathrm{p}>$ 0.01 ; Fig. 3). The first axis, which accounted for $67.6 \%$ of the variance, was highly correlated with temperature $(-0.77)$ and salinity $(0.58)$. This first axis models a time and site gradient that distinguishes between species found in the warmer month (May) from the cooler months (March, April) and at low salinity sites versus those found at higher salinity sites. Species such as Strongylura marina (SM), Syngnathus scovelli (SS) and Penaeus spp. (PS) were associated with higher temperatures, while species such as Citharichthys spilopterus (CP) and Leiostomus xanthurus (LX) were associated with higher salinity. The second axis, which accounted for $13.2 \%$ of the variance, was best defined by inundation (-0.30). Species such as Callinectes sapidus (CS) and Lagodon rhomboids (LR) were associated with edges that were more highly inundated.

\section{DISCUSSION}

Nekton assemblages differed greatly by season and by marsh edge physical variation. Non-vegetated marsh edges with shallower slopes and greater tidal inundation supported higher abundances of organisms in general; edges with steeper slopes and more complex edge morphologies (i.e. greater irregularity) supported more diverse and species-rich assemblages. While the habitat value of flooded vegetated marsh edges has been reported in numerous studies (i.e. Turner 1977, Minello \& Rozas 2002), our study focused on nekton community and habitat use of nonvegetated marsh edges (i.e. the water edge of marsh). This information contributes to our understanding of nekton habitat use patterns and can help inform the design of marsh restoration and creation projects. 


\section{Physical habitat variation and nekton assemblage}

The influence of the physical structure of habitats on the distribution of individual species and community assemblages has long been recognized (Grinnell 1917, Gause 1934); variation in physical properties of a habitat can influence species abundances and composition by affecting the availability of refuge and resources, and the rate of resource acquisition (Hixon \& Beets 1993, Griffiths et al. 2006). In aquatic coastal environments, numerous manipulation and sampling experiments demonstrate higher nekton densities and richness in more physically complex habitats (Ohman \& Rajasuriya 1998). These more complex habitats tend to have vegetation or crevices that provide greater refuge, and a higher diversity of microhabitats (Hixon \& Beets 1993, James \& Heck 1994). Most of these studies were conducted along rocky shorelines, in coral reef environments or in seagrass beds; only a few studies, however, have quantified marsh edge complexity or, specifically, examined nekton community habitat use along the non-vegetated side of salt marsh edges.

Two previous studies have suggested that the geomorphology of the microhabitat may be an indicator of the habitat value of the adjacent marsh (McIvor \& Odum 1988, Hettler 1989). McIvor \& Odum (1988) found higher numbers of organisms and different species composition at marsh sites adjacent to shallowsloped depositional banks compared with deeper erosional banks in a tidal freshwater marsh in Virginia, USA. They suggested that this finding may be due to a combination of lower predation pressure and higher food availability. Hettler (1989), working in saltmarsh cordgrass habitat in North Carolina, USA, found that rivulet marsh habitat (bordered by shallow, lowenergy intertidal microhabitat) had higher numbers and biomass of organisms, but lower numbers of species compared with channel marsh habitat (bordered by deeper water, increased wave energy and subtidal microhabitat). While both these studies sampled on the marsh surface, they related their findings to adjacent non-vegetated marsh edge habitat, and both studies support our findings.

The higher numbers of organisms found by McIvor \& Odum (1988) and Hettler (1989) on marsh adjacent to the shallower sloped sites is similar to our finding of greater abundance of organisms along gently sloped non-vegetated edge habitats and probably reflects the increased inundation time of adjacent marsh and greater accessibility to the marsh surface, which allows species to exploit the inner marsh by providing earlier and prolonged access across all tidal cycles (Rozas et al. 1988, Rozas \& Reed 1993). Along the Gulf of Mexico coast, resident species have been shown to congregate in shallow subtidal areas that provide earlier access to vegetated intertidal habitats during flood tides (Rozas \& Zimmerman 2000, Minello \& Rozas 2002). Selection of shallow subtidal and vegetated intertidal habitats by juveniles and other small nekton may also be linked to predation; small fishes are often too small to be of interest to avian predators (Knieb 1982) and, thus, may seek out the shallowest water habitats to escape predation by larger piscivorous fishes (Ruiz et al. 1993).

In contrast, the deeper water, higher shoreline irregularity and exposed root systems of our cut-bank habitats may offer a more complex habitat and increased refuge opportunities leading to greater species number and diversity. This finding is similar to that of Hettler (1989), who found greater species number on sites bordering deeper subtidal microhabitats. For some small estuarine residents, prey fish and juveniles, the cut-bank habitats may offer valuable refuge as evidenced by greater abundances of many of these small species in both fall and spring (i.e. Menidia beryllina, Brevoortia patronus, Anchoa mitchilli). Measures of nekton community such as diversity and species number were found to be positively associated with slope (fall: diversity; spring: diversity and species number). The cut-bank habitats may support this greater number of species by providing more microhabitats based on water depth and greater shoreline irregularity. These steeper edges, which offer deeper water, may also provide habitat for predatory fish to forage or to wait to capture smaller prey organisms as they leave the adjacent marsh surface, similar to what has been suggested for tidal creeks along the Atlantic coast (Kneib 2000).

Numerous studies on marsh edge habitat along the northern coast of the Gulf of Mexico indicate that nekton use of vegetated marsh edge (i.e. $1 \mathrm{~m}$ on vegetation side of marsh-water interface) is strongly associated with water depth and marsh elevation, with lower water depths and elevation associated with higher nekton densities (Rakocinski et al. 1993, Akin et al. 2003, Zeug et al. 2007). In fact, Rozas \& Zimmerman (2000) suggest that priority should be given to constructing low marsh edge to maximize nekton habitat as it offers greater accessibility to valuable marsh habitat. Our study supports the finding that sloped shorelines provide more marsh access (i.e. lower slopes, lower elevation), support high abundances of nekton as nekton move on and off the marsh, and potentially provide a shallow water refuge. Cut-bank shorelines may be equally valuable, as these steeper edge habitats support greater numbers of species, which may be due to more refuge opportunities when the marsh surface is not flooded, especially for fish avoiding both aquatic and aerial predators. 


\section{Temporal variation in nekton community}

The lack of consistent nekton-environment relationships across seasons reflects the different habitat requirements of the fall and spring nekton communities (Rakocinski et al. 1993, Gelwick et al. 2001). Estuaries undergo seasonal and annual changes in physical variables (Livingston 1976), and nekton assemblages may fluctuate both temporally and spatially, in part, because highly motile nekton can follow large-scale changes in the environment (Ross \& Epperly 1985, Rountree \& Able 2007); as such, salinity and temperature are most frequently cited as having a strong influence on nekton assemblages (Loneragan et al. 1986, Akin et al. 2003).

While salinity and temperature may be key to controlling nekton communities on a large macro-habitat scale, nekton probably use a variety of estuarine micro-habitats (i.e. Rountree \& Able 2007) that vary from tidal or diel shifts in environmental conditions. Within the salt marsh, tidal and diel changes in the environmental gradient can affect the location and position of food resources, refuge, predators and competitors on a micro-scale level, all of which influence habitat use by nekton (Rozas \& Hackney 1984, Rozas \& Odum 1988). While numerous studies of vegetated marsh edge suggest that flooded vegetated marsh edge has high habitat quality (e.g. Minello 1999), our study demonstrates that the soft bottom adjacent edges also support nekton, though differences in sampling gear make direct comparisons of abundances difficult. However, as nekton clearly do not use vegetated marsh surfaces when they are not flooded, tidal and water-level changes along marsh edges may establish a cyclic shift in habitat quality to which nekton respond. Our findings that suggest non-vegetated bottom marsh edges adjacent to higher elevation marshes support high diversity and a unique assemblage of species compared with non-vegetated marsh edges adjacent to sloping, lower elevation marsh support the suggestion by Rountree \& Able (2007): there is a need to examine nekton habitat use patterns along a tidal elevation gradient from high marsh to adjacent subtidal bottom if such patterns are to be fully understood.

In conclusion, differences in non-vegetated marsh edge morphology were linked to differences in nekton use and community assemblages. Steeper, more complex edges supported diverse nekton communities, whereas more gently sloping edge habitats supported higher abundances of resident species. Variation in edge morphology results in differences in habitat function for individual species at any given time; at a minimum, the non-vegetated marsh edge provides refuge along different depth gradients, particularly when the adjacent vegetated marsh is not flooded. Simultaneous sampling across the marsh edge gradient would provide a better understanding of nekton use patterns of flooded marsh surfaces and the adjacent nonvegetated edge habitats.

Acknowledgements. We thank Bryan Gossman, Brian Heimann, Matt Messina, Tim Patton, Bryan Piazza, Sarai Piazza, John Plunket, Aaron Podey, Nicole Salvi, Chad Thomas and the summer 2004 Coastal Ecology class from Southeastern Oklahoma State University for field and laboratory assistance. We also thank Dr. Michael Kaller for comments and statistical advice that improved this manuscript. This project was funded by a grant from the Louisiana Department of Wildlife and Fisheries.

\section{LITERATURE CITED}

Akin S, Winemiller KO, Gelwick FP (2003) Seasonal and spatial variations in fish and macrocrustacean assemblage structure in Mad Island Marsh estuary, Texas. Estuar Coast Shelf Sci 57:269-282

Arrivillaga A, Baltz DM (1999) Comparison of fishes and macroinvertebrates on seagrass and bare-sand sites on Guatemala's Atlantic coast. Bull Mar Sci 65:301-319

Baltz DM, Rakocinski CF, Fleeger JW (1993) Microhabitat use by marsh-edge fishes in a Louisiana estuary. Environ Biol Fishes 36:109-126

Chambers JR (1992) Coastal degradation and fish population losses. In: Stroud RH (ed) Stemming the tide of coastal fish habitat loss. National Coalition for Marine Conservation, Savannah, GA, p 45-51

Conner WH, Day JW Jr (1987) The ecology of Barataria Basin, Louisiana: an estuarine profile. US Fish Wildl Serv Biol Rep 85(7.13):1-7

Gauch HG (1982) Multivariate analysis in community ecology. Cambridge University Press, Cambridge

Gause GF (1934) The struggle for existence. Hafner, New York

Gelwick FP, Akin S, Arrington DA, Winemiller KO (2001) Fish assemblage structure in relation to environmental variation in a Texas Gulf coastal wetland. Estuaries 24:285-296

Griffiths SP, Davis AR, West RJ (2006) Role of habitat complexity in structuring temperate rockpool ichthyofaunas. Mar Ecol Prog Ser 313:227-239

Grinnell J (1917) The niche relationships of the California thrasher. Auk 34:427-433

Heck KL, Hays G, Orth RJ (2003) Critical evaluation of the nursery role hypothesis for seagrass meadows. Mar Ecol Prog Ser 253:123-136

Hettler WF (1989) Nekton use of regularly-flooded saltmarsh cordgrass habitat in North Carolina, USA. Mar Ecol Prog Ser 56:111-118

Hixon MA, Beets JP (1993) Predation, prey refuges, and the structure of coral-reef fish assemblages. Ecol Monogr 63: 77-101

James PL, Heck KL (1994) The effects of habitat complexity and light intensity on ambush predation within a simulated seagrass habitat. J Exp Mar Biol Ecol 176:187-200

Jongman RHG, ter Braak CJF, Van Tongeren OFR (1995) Data analysis in community and landscape ecology. Cambridge University Press, London

Kneib RT (1982) The effects of predation by wading birds (Ardeidae) and blue crabs (Callinectes sapidus) on the population structure of the common mummichog, Fundulus heteroclitus. Estuar Coast Shelf Sci 14:159-165 
Kneib RT (2000) Salt marsh ecoscapes and production transfers by estuarine nekton in the southeastern United States. In: Weinstein MP, Kreeger DA (eds) Concepts and controversies in tidal marsh ecology. Kluwer Academic Publishers, Boston, MA, p 267-314

Livingston RJ (1976) Diurnal and seasonal fluctuations of organisms in a north Florida estuary. Estuar Coast Mar Sci $4: 373-400$

Loneragan NR, Potter IC, Lenanton RC, Caputi N (1986) Spatial and seasonal differences in the fish fauna in the shallows of a large Australian estuary. Mar Biol 92:575-586

McIvor CC, Odum WE (1988) Food, predation risk, and microhabitat selection in a marsh fish assemblage. Ecology 69: $1341-1351$

Minello TJ (1999) Nekton densities in shallow estuarine habitats of Texas and Louisiana and the identification of essential fish habitat. In: Benaka LR (ed) Fish habitat: essential fish habitat and habitat rehabilitation. Symposium 22, American Fisheries Society, Bethesda, MD, p 43-75

Minello TJ, Rozas LP (2002) Nekton in Gulf coast wetlands: fine-scale distributions, landscape patterns, and restoration implications. Ecol Appl 12:441-455

Ohman MC, Rajasuriya A (1998) Relationships between habitat structure and fish communities on coral and sandstone reefs. Environ Biol Fishes 53:19-31

Patterson CS, Mendelssohn IA (1991) A comparison of physicochemical variables across plant zones in a mangal/salt marsh community in Louisiana. Wetlands 11:139-161

Rakocinski CF, Baltz DM, Fleeger JW (1993) Correspondence between environmental gradients and the community structure of marsh-edge fishes in a Louisiana estuary. Mar Ecol Prog Ser 80:135-148

Ross SW, Epperly SP (1985) Utilization of shallow estuarine nursery areas by fishes in Pamlico Sound and adjacent tributaries in North Carolina. In: Yanez-Arancibia A (ed) Fish community ecology in estuaries and coastal lagoons: towards an ecosystem integration. Universidad Nacional Autonoma de Mexico, Universitaria, Mexico City, p 207-232

Rountree RA, Able KW (2007) Spatial and temporal habitat use patterns for salt marsh nekton: implications for ecological functions. Aquat Ecol 41:25-45

Rozas LP (1995) Hydroperiod and its influence on nekton use

Editorial responsibility: Otto Kinne, Oldendorf/Luhe, Germany of the salt marsh: a pulsing ecosystem. Estuaries 18: $579-590$

Rozas LP, Hackney CT (1984) Use of oligohaline marshes by fishes and macrofaunal crustaceans in North Carolina. Estuaries 7:213-224

Rozas LP, Odum WE (1988) Occupation of submerged aquatic vegetation by fishes: testing the roles of food and refuge. Oecologia 77:101-106

Rozas LP, Reed DJ (1993) Nekton use of marsh-surface habitats in Louisiana (USA) deltaic salt marshes undergoing submergence. Mar Ecol Prog Ser 96:147-157

Rozas LP, Zimmerman R (2000) Small-scale patterns of nekton use among marsh and adjacent shallow nonvegetated areas of the Galveston Bay Estuary, Texas (USA). Mar Ecol Prog Ser 193:217-239

Rozas LP, McIvor CC, Odum WE (1988) Intertidal rivulets and creek banks: corridors between tidal creeks and marshes. Mar Ecol Prog Ser 47:303-307

Ruiz GM, Hines AH, Posey MH (1993) Shallow water as a refuge habitat for fish and crustaceans in non-vegetated estuaries: an example from Chesapeake Bay. Mar Ecol Prog Ser 99:1-16

SAS Institute (1989) SAS/STAT user's guide, version 6, 4th edn, Vol 1. SAS Institute, Cary, NC

Sogard SM, Powell GN, Holmquist JG (1987) Epibenthic fish communities on Florida Bay banks: relations with physical parameters and seagrass cover. Mar Ecol Prog Ser 40:25-39

ter Braak CJF, Smilauer P (2002) CANOCO reference manual and CanoDraw for Windows user's guide: software for canonical community ordination (version 4.5). Microcomputer Power, Ithaca, NY

Turner RE (1977) Intertidal vegetation and commercial yields of penaeid shrimp. Trans Am Fish Soc 106:411-416

Valesini FJ, Potter IC, Clarke KR (2004) To what extent are the fish compositions at nearshore sites along a heterogeneous coast related to habitat type? Estuar Coast Shelf Sci 60:737-754

Zar JH (1999) Biostatistical analysis, 4th edn. Prentice Hall, Upper Saddle River, NJ

Zeug SC, Shervette VR, Hoeinghaus DJ, Davis SE III (2007) Nekton assemblage structure in natural and created marsh-edge habitats of the Guadalupe Estuary, Texas, USA. Estuar Coast Shelf Sci 71:457-466

Submitted: June 5, 2007; Accepted: September 18, 2007

Proofs received from author(s): February 11, 2008 